\title{
WIND REGIMES AND HEAT EXCHANGE ON GLACIER DE SAINT-SORLIN
}

\author{
By S. MARTiN \\ (Laboratoire de Glaciologie du C.N.R.S., 2, rue Très-Cloîtres, $3^{803}$ I Grenoble, France)
}

\begin{abstract}
Abstracr. During the summers of 1969 and 1970 , we recorded in the ablation zone of the Glacier de St-Sorlin (Massif des Grandes Rousses, France) temperature, air moisture, and wind profiles, as well as the radiation balance and the daily ablation. Numerous profiles characterize a katabatic flow following the line of greatest slope, and there appears to be a correlation between the speed of the "glacier wind" and the corresponding temperature gradients. Computed according to Prandtl's theory of turbulent transfers, the flux of sensible and latent heat added to the radiation flux leads to theoretical values for the daily melting in good agreement with the measured values. The relative importance of the radiation balance on the melting of the snow is $57 \%$; that of the sensible heat flux is $43 \%$; the latent heat flux is very weak and negative.
\end{abstract}

RÉsumé. Régim: des vents et transferts thermiques sur le Glacier de Saint-Sorlin. Durant les étés I969 et 1970, nous avons enregistré sur la zone d'ablation du glacier de St-Sorlin (Massif des Grandes Rousses, France) des profils de température et d'humidité de l'air, des profils des vitesses du vent, ainsi que le bilan radiatif et l'ablation journalière. Un certain nombre de ces profils caractérisent un écoulement catabatique suivant la ligne de plus grande pente et il apparait une corrélation entre la vitesse de ce "vent de glacier" et le gradient de températures correspondant. Calculés à partir de la théorie des transferts turbulents de Prandtl, les flux de chaleur sensible et de chaleur latente ajoutés aux flux de rayonnement conduisent à une valeur théorique de la fusion quotidienne en bon accord avec la valeur mesurée. L'importance relative du bilan radiatif sur la fusion de la glace est de $57 \%$; celle du bilan de chaleur sensible de $43 \%$; le bilan de chaleur latente est très faible et négatif.

Zusammenfassung. Windsysteme und Wärmeaustausch am Glacier de Saint-Sorlin. Im Sommer 1969 und 1970 wurden in der Ablationszone des Glacier de St-Sorlin (Massif des Grandes Rousses, Frankreich) Temperatur-, Luftfeuchte- und Windprofile sowie die Strahlungsbilanz und die tägliche Ablation registriert. Zahlreiche Profile sind durch eine katabatische Strömung gekennzeichnet, die den Linien grösster Neigung folgt; die Geschwindigkeit des "Gletscherwindes" scheint mit den entsprechenden Temperaturgradienten korreliert zu sein. Die nach der Prandtlschen Theorie des turbulenten Austausches errechnete Summe des fühlbaren und latenten Wärmeflusses mit dem Strahlungsfluss führt zu theoretischen Werten für die tägliche Ablation, die gut mit den gemessenen Werten übereinstimmen. Der relative Einfluss der Strahlungsbilanz auf die Schneeschmelze beträgt $57 \%$, während der des fühlbaren Wärmeflusses $43 \%$ beträgt; der Fluss latenter Wärme ist sehr schwach und negativ.

\section{INTRODUGTION}

Located in the Massif des Grandes Rousses (France), the Glacier de Saint-Sorlin has been the subject of various glaciological studies since 1957 (Lliboutry, 1974). Among these studies managed by the Laboratorie de Glaciologie of C.N.R.S. we undertook the measurement of heat exchange during summer. Measurements were carried out in the ablation zone $(2712 \mathrm{~m})$ from 12 August to 16 September 1969 and from I September to 21 September 1970 on the bare ice. The 1970 measurements, more complete because we were able to analyse a Io $\mathrm{m}$ layer, will essentially be used to study the kinetic and thermal behaviour of air masses in contact with the glacier. The 1969 measurements, although limited to the first $2 \mathrm{~m}$ are more homogeneous and can provide an approximate heat balance.

The experimental study of heat balance consists of determining each term of the energy conservation equation:

$$
B-Q+L_{\mathrm{S}} E-F-Q_{\mathrm{I}}=\mathrm{o}
$$

where $B$ is the radiation balance, $Q$ the sensible heat flux, $L_{\mathrm{S}} E$ the latent heat flux, $F$ the melting ice heat flux, and $Q_{I}$ the conductive heat flux. Let us write $Q_{I}=0$ for a temperate glacier in the ablation period. 


\section{Apparatus}

Each meteorological element (anemometers, thermometers, and the thermopile) gives impulses whose frequency is a function of the intensity of the measured quantity. Every hour, a programmer provides an average measurement for each of the meteorological variables by counting the impulses during $605 \mathrm{~s}$.

\subsection{Wind velocity}

The five-cup anemometers have a lower limit of $0.3 \mathrm{~m} \mathrm{~s}^{-1}$ and a mean precision of approximately $0.05 \mathrm{~m} \mathrm{~s}^{-1}$. Each wind-speed profile is obtained from three measuring points $(0.5 \mathrm{~m}$, $\mathrm{I} \mathrm{m}$ and $2 \mathrm{~m}$ ). In 1970 , we provided for an additional point, ranging between 2 and $10 \mathrm{~m}$.

\subsection{Temperature and humidity}

The apparatus used consists of a thermograph with digital remote indication (Poggi and others, 1967). The thermistors, protected by a series of double screens, are placed at $0.5 \mathrm{~m}, \mathbf{I} \mathrm{m}$ and $2 \mathrm{~m}$; in 1970 we added another one between 2 and $10 \mathrm{~m}$. Their accuracy is about $0.05 \mathrm{deg}$.

The water vapour is calculated at $0.5 \mathrm{~m}$ and $2 \mathrm{~m}$ from the temperature difference between wet and dry thermistors placed at the same level:

$$
f=f_{\mathrm{w}}{ }^{\prime}-A p\left(\theta-\theta^{\prime}\right)
$$

where $\theta^{\prime}$ is the temperature of the wet thermistor, $\theta$ the temperature of the dry thermistor, $p$ the atmospheric pressure, and $f_{w^{\prime}}{ }^{\prime}$ the vapour pressure over water. This is computed from tables which gives $f_{w^{\prime}}$ as a function of temperature.

Since the ventilation comes about naturally, we adapted the psychrometric constant $A$ to the wind velocity according to Petit's (1958) curves (Fig. I).

\subsection{Net radiation}

The total radiation balance is measured directly by a thermopile with a telluride-copper thermocouple blackened on its two faces and placed at $1.5 \mathrm{~m}$. Its sensitivity is $15.77 \mathrm{mV}$ $\mathrm{kW}^{-1} \mathrm{~m}^{2}$.

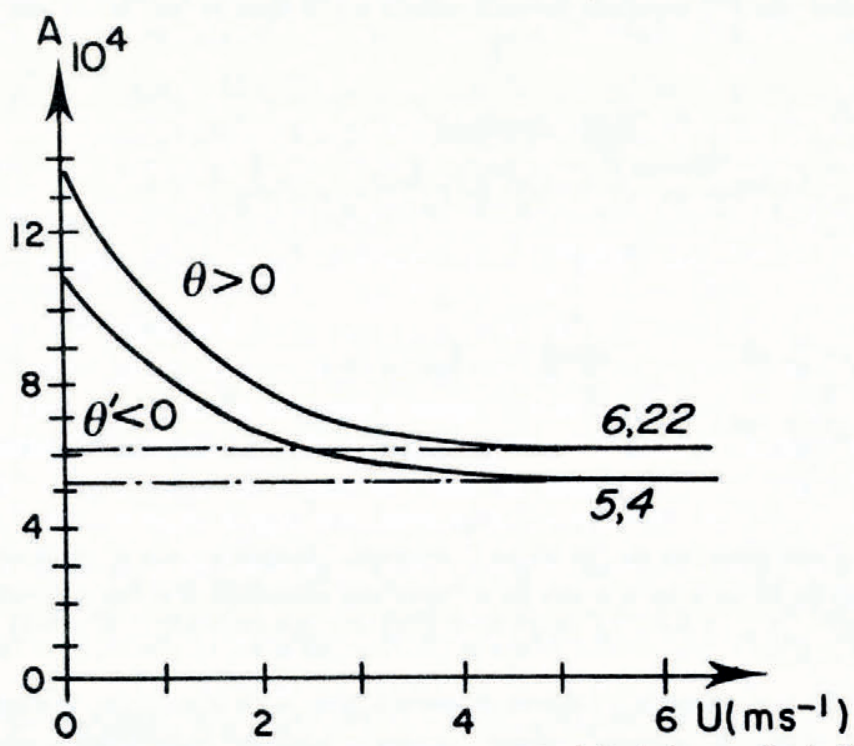

Fig. I. Variation of the psychrometric constant with wind velocity according to Petit. 
Largely due to poor stability with temperature of the apparatus, the absolute error is about $\pm 10 \mathrm{~W} \mathrm{~m}^{-2}$.

\subsection{Run-off measurements}

At $2 \mathrm{~km}$ from the meteorological station, a float recorder enabled us to follow the variations in height of the water of Rieu Blanc, a stream that collects the greatest part of melt water from the glacier. The calibration curve giving stream discharge is obtained from dilution techniques (André, r964).

\subsection{Complementary measurements}

At $9.00 \mathrm{~h}$ and $\mathrm{I} 8.00 \mathrm{~h}$ daily, we noted: atmospheric pressure, precipitation, nebulosity, and ablation at four stakes placed around the station.

This apparatus, largely conceived by the Laboratoire de Glaciologie, had the advantage of being easy to handle and not requiring much electricity.

\section{WIND-SPEED AND TEMPERATURE PROFILES}

\subsection{In the presence of a weak thermal gradient}

When the surrounding air temperature is near $0^{\circ} \mathrm{C}$ or when a sufficient wind assures good mixing in the lowest layer, the wind-speed profiles can be approximated by Prandtl's semi-empirical law (Equation (2))

$$
u=\frac{u_{*}}{k} \ln \left[\frac{z}{z_{0}}\right]
$$

or by the more general Deacon's empirical law (Equation (3)) which reduces to Equation (2) as $\beta \rightarrow \mathrm{I}$ (Sutton, I953):

$$
u=\frac{u_{*}}{k(\mathrm{I}-\beta)}\left[\left(\frac{z}{z_{0}}\right)^{\mathrm{I}-\beta}-\mathrm{I}\right]
$$

where $u_{*}$ is the friction velocity defined by the relation $\tau_{0}=\rho u_{*}{ }^{2}, \tau_{0}$ the surface shear stress per unit area, $\rho$ the air density, $z_{0}$ the roughness parameter, $k$ is von Kármán's constant, $u$ the wind velocity, and $z$ the height above the ice.

Table I gives the results of 18 profiles.

\begin{tabular}{|c|c|c|c|c|c|c|c|c|c|}
\hline Date & $\stackrel{t}{h}$ & $\begin{array}{c}v_{0.5} \\
\mathrm{~cm} \mathrm{~s}^{-1}\end{array}$ & $\begin{array}{c}v_{\mathrm{I}} \\
\mathrm{cm} \mathrm{s}^{-1}\end{array}$ & $\begin{array}{c}v_{2} \\
\mathrm{~cm} \mathrm{~s}^{-1}\end{array}$ & $\begin{array}{l}\theta_{2} \\
{ }^{\circ} \mathrm{C}\end{array}$ & $\mathrm{cm} \mathrm{s}^{u_{*}}$ & $\begin{array}{c}z_{0} \\
\mathrm{~cm}\end{array}$ & $\beta$ & $(R i)$ \\
\hline \multirow{10}{*}{ 15 September: } & 15 & 257 & 297 & $33^{8}$ & 1.72 & 24.4 & 0.62 & 1.00 & -0.013 \\
\hline & 16 & 361 & $4^{21}$ & 495 & 1.32 & 40.4 & 1.23 & 0.69 & -0.05 \\
\hline & 17 & 328 & 373 & 439 & I. 16 & 33.4 & 0.87 & 0.45 & -0.01 \\
\hline & 18 & 470 & 535 & 615 & 0.99 & $43 \cdot 7$ & 0.57 & 0.70 & -0.002 \\
\hline & 19 & $38 \mathrm{I}$ & 426 & 487 & 0.88 & 31.9 & 0.36 & 0.57 & -0.002 \\
\hline & 20 & 366 & 415 & 477 & 1.12 & 33.4 & 0.54 & 0.67 & -0.002 \\
\hline & 21 & 395 & 447 & 510 & I.1 I & 34.6 & 0.44 & 0.73 & -0.007 \\
\hline & 22 & 504 & 574 & 658 & 0.80 & 46.4 & 0.55 & 0.74 & -0.004 \\
\hline & 23 & 483 & 553 & 635 & I.13 & 45.8 & 0.62 & 0.77 & ? \\
\hline & 24 & 423 & 477 & 533 & 1.13 & 33.1 & 0.24 & 0.66 & -0.001 \\
\hline \multirow[t]{8}{*}{16 September: } & 1 & 447 & 502 & 571 & 0.85 & $37 \cdot 3$ & 0.35 & 0.68 & -0.001 \\
\hline & 2 & 378 & $43^{8}$ & 500 & 0.54 & $3^{6.7}$ & 0.69 & 1.00 & -0.002 \\
\hline & 3 & 321 & 373 & 424 & 0.62 & $3^{1.0}$ & 0.67 & 1.00 & 0.004 \\
\hline & 4 & $34^{\circ}$ & $3^{89}$ & 437 & 0.50 & 29.2 & 0.39 & 1.00 & -0.004 \\
\hline & 5 & 401 & 454 & $5^{1} 4$ & 0.57 & 34.0 & 0.37 & $0.8 \mathrm{I}$ & -0.002 \\
\hline & 6 & 379 & $43^{1}$ & $4^{85}$ & $0.5^{8}$ & 31.9 & 0.36 & 0.95 & -0.003 \\
\hline & 7 & 405 & 471 & 543 & 2.03 & 41.6 & 0.87 & 0.88 & $-0.00 \mathrm{I}$ \\
\hline & 8 & 376 & $4^{16}$ & 466 & 1.92 & 27.1 & 0.16 & 0.68 & -0.006 \\
\hline
\end{tabular}

Table I. Profiles measured on 15 AND 16 September 1969 
Richardson's number (Ri) (Priestley, 1959) interprets the ratio of the convective forces represented by the sensible heat flux to the shearing stresses represented by the flux of momentum:

$$
(R i)=\frac{g}{T} \frac{\mathrm{d} \theta}{\mathrm{d} z}\left(\frac{\mathrm{d} u}{\mathrm{~d} z}\right)^{-2}
$$

where $g$ is the acceleration due to gravity, $T$ the air temperature, and $\theta$ the potential temperature. Richardson's numbers were calculated at $1.08 \mathrm{~m}$ using the values of the velocities and temperatures at $0.5 \mathrm{~m}$ and $2 \mathrm{~m}$. They vary from 0.013 to 0.04 and characterize a near neutral atmosphere.

The parameter $z_{0}$ is calculated from the logarithmic law (2) and $\beta$ from Deacon's law (3):

$$
\begin{aligned}
& 0.0016<z_{0}<0.0123 \mathrm{~m} \text { with } \bar{z}_{0}=0.005^{8} \mathrm{~m}, \\
& 0.45<\beta<\mathrm{w} \quad \text { with } \bar{\beta}=0.82 .
\end{aligned}
$$

With temperature inversion, $(R i)<0.16$, the logarithmic law again is a good approximation (Fig. 2).

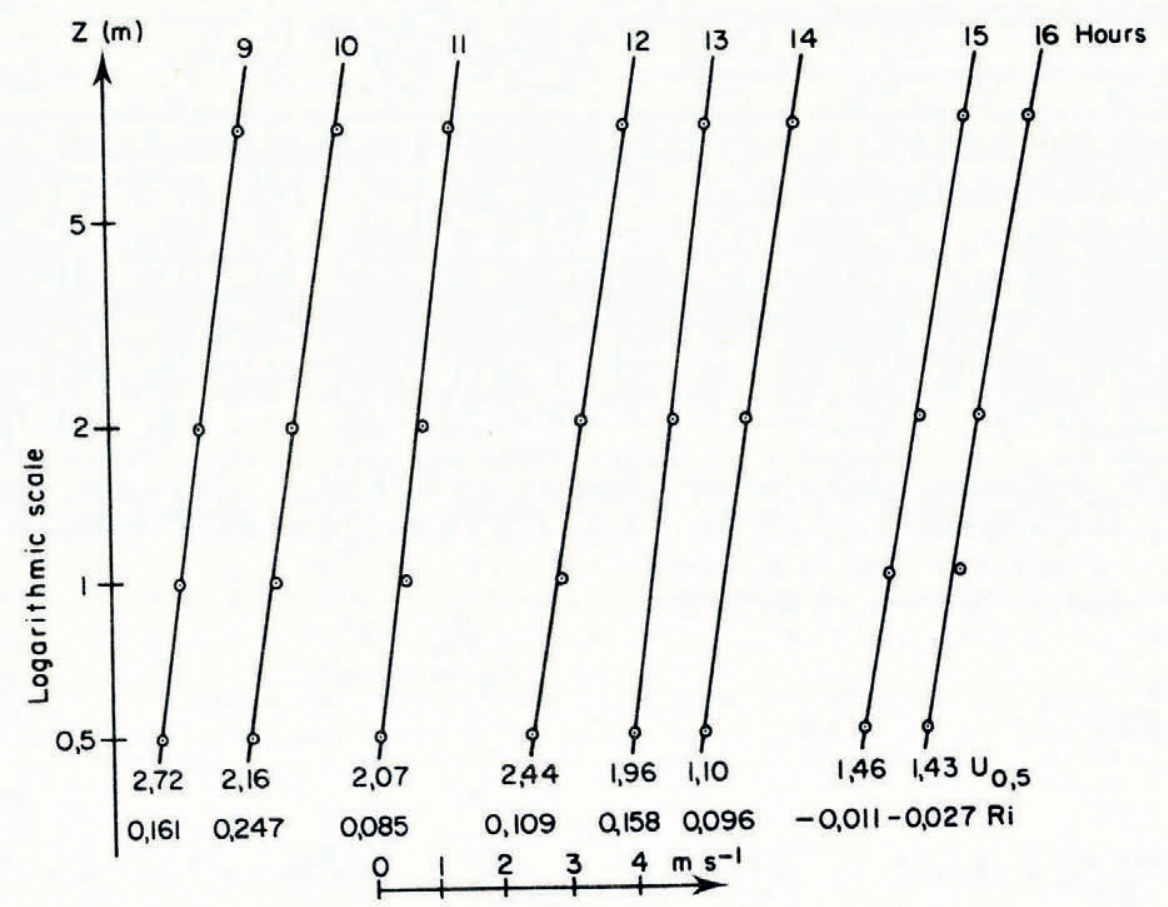

Fig. 2. Wind-speed profiles for winds blowing from the north-west, 5 September 1970.

3.2. In the presence of a strong thermal gradient: three days of glacier wind ( 18,19 and 20 September 1970)

3.2.1. Wind-speed profiles. The influence of stratification on the wind-speed profiles (Webb, 1970; Grainger and Lister, 1966; Arya, 1972) becomes more complicated on inclined surfaces because it also produces an acceleration of layers that are more dense (Ellison and Turner, 1959, 1960). If the stratification is sufficient, a katabatic flow appears on the glacier and follows the line of greatest slope: this is the "glacier wind" (Hoinkes, 1954). 
During three days without a dominating wind, we took advantage of the clear weather that permitted the surrounding air to reach elevated temperatures and the appearance of a strong stratification at the level of the glacier $((R i)>0.25)$. All of the wind-speed profiles are characterized by a maximum located between $\mathrm{I}$ and $5 \mathrm{~m}$.

Prandtl's analysis (1952) of winds of local origin and, notably, mountain and valley winds, leads to wind-speed profiles of the form:

$$
u_{z}=C \sin (Z / l) \exp (-Z / l)
$$

where $C$ and $l$ are constants, and $Z$ is the height above the inclined surface and measured perpendicular to it.

In our case, since the glacier has very little slope $\left(7^{\circ}\right)$ at the level of the measuring point, it will be considered that $Z \approx z$; the height $z$ is taken vertically above this point.

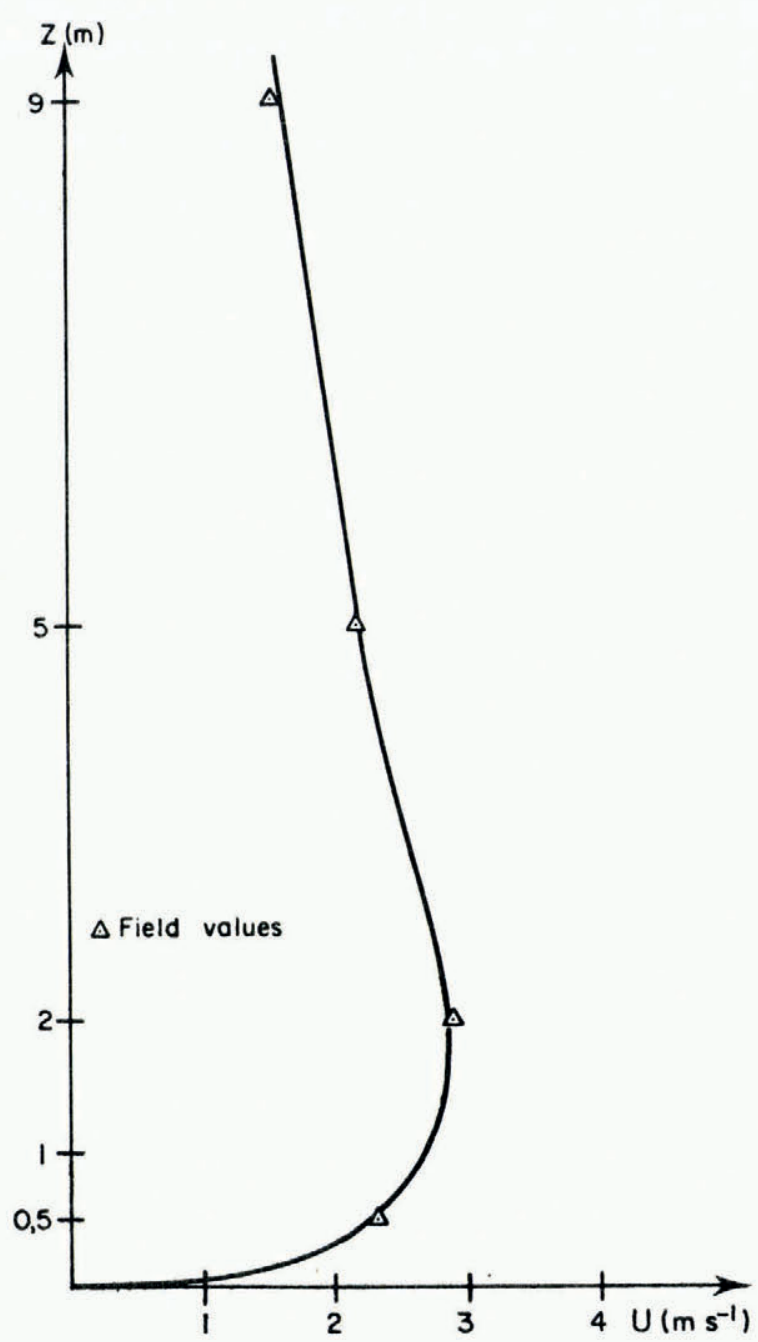

Fig. 3. 20 September 1970. Fitting of a mean wind-speed profile by the equation: $u_{z}=1.02 \ln (z / 0.045 \mathrm{~m}) \exp -(z / 6.53 \mathrm{~m})$. 
According to Equation (5), the velocity vanishes and the changes sign when $Z=\pi l$ and the first maximum velocity is attained when

$$
\frac{\partial u}{\partial z}=0 \quad \text { or } \quad \frac{C}{l}[\cos Z|l-\sin Z| l] \exp (-Z \mid l)=0 \quad \text { or } \quad Z=\frac{\pi l}{4} .
$$

Thus, the height of vanishing wind is four times greater than the height of maximum velocity. This is not the case for the profiles we recorded since we found notable winds above $9 \mathrm{~m}$, while the maximum is located between $\mathrm{I} \mathrm{m}$ and $2 \mathrm{~m}$ (Fig. 3).

Among all the simple empirical laws that permit description of the recorded profiles, the one that is best suited is:

$$
u_{z}=A \ln (z / a) \exp (-z / b),
$$

where $A, a$ and $b$ are constants. When the stratification diminishes, $b \rightarrow \infty$ and we arrive again at the logarithmic law. Three measuring points are sufficient to calculate $A, a$ and $b$. For instance, we have shown in Figure 3, the average profile calculated on 20 September 1970 from $8.00 \mathrm{~h}$ to $17.00 \mathrm{~h}$

$$
\bar{u}_{z}=1.02 \ln (z / 0.045) \exp (-z / 6.53)
$$

Taking into account only velocities above $1 \mathrm{~m} \mathrm{~s}^{-1}$, we calculated the values of the parameters $a, b$ and $A$ for $5^{\circ}$ profiles and traced their distributions (Fig. 4).

For $a$, the most abundant class is that which corresponds to the area of variation of $z_{0}$ in the case of logarithmic profiles (0.0016 m $>z_{0}>0.0123 \mathrm{~m}$ ).

The distribution of the parameter $b$ has two maxima because it is necessary to separate the "diurnal" period (in white on Figure 4) from the "nocturnal" period (shaded on Figure 4). At night, the values for $b$ are greater than during the day. This is probably due to the fact that the mountain wind that develops at this time blows in the same direction as the glacier wind and superimposes itself. Therefore, the ambient air is swept along by something other than the glacier wind which causes an augmentation of velocities and especially of the parameter $b$.

Table II shows the average values of the coefficients $a, b$ and $A$ during the "diurnal"

\begin{tabular}{|c|c|c|c|c|c|}
\hline Date & $\underset{\mathrm{h}}{\text { Time }}$ & Profiles & $\begin{array}{l}\bar{a} \\
\mathrm{~m}\end{array}$ & $\begin{array}{c}b \\
\mathrm{~m}\end{array}$ & $\underset{\mathrm{m} \mathrm{s}^{-1}}{A}$ \\
\hline 18 September & $9^{-17}$ & 7 & 0.019 & 8.67 & 0.79 \\
\hline 18-19 September & $22-6$ & 4 & 0.009 & 14.45 & $0.5^{1}$ \\
\hline 19 September & $7-17$ & 6 & 0.016 & 6.98 & 0.64 \\
\hline 19-20 September & $18-4$ & 10 & 0.016 & 12.21 & 0.95 \\
\hline 20 September & $8-17$ & 10 & 0.045 & 6.53 & 1.02 \\
\hline 20-2 I September & $18-6$ & 9 & 0.015 & 10.72 & 0.86 \\
\hline
\end{tabular}
period on one hand and nocturnal on the other hand.

'Table II. Average values of the parameters $a, b$ and $A$

3.2.2. Temperature profiles. Taylor (mentioned by Sutton, 1953) studied the case where a hot air mass blows over a cold horizontal surface. If that surface stays at $0^{\circ} \mathrm{C}$, which is the case of the glacier during the "diurnal" period, and if $T_{0}$ is the temperature of the hot air layer, the vertical temperature distribution fits the equation

$$
\theta_{(z)}=T_{0} \operatorname{erf}\left[z /\left(4 K_{\mathrm{h}} t\right)^{\mathbf{l}}\right]
$$

where $t$ is the time from the beginning of the contact between the hot air and the cold source, $K_{\mathrm{h}}$ the turbulent heat exchange coefficient, and 

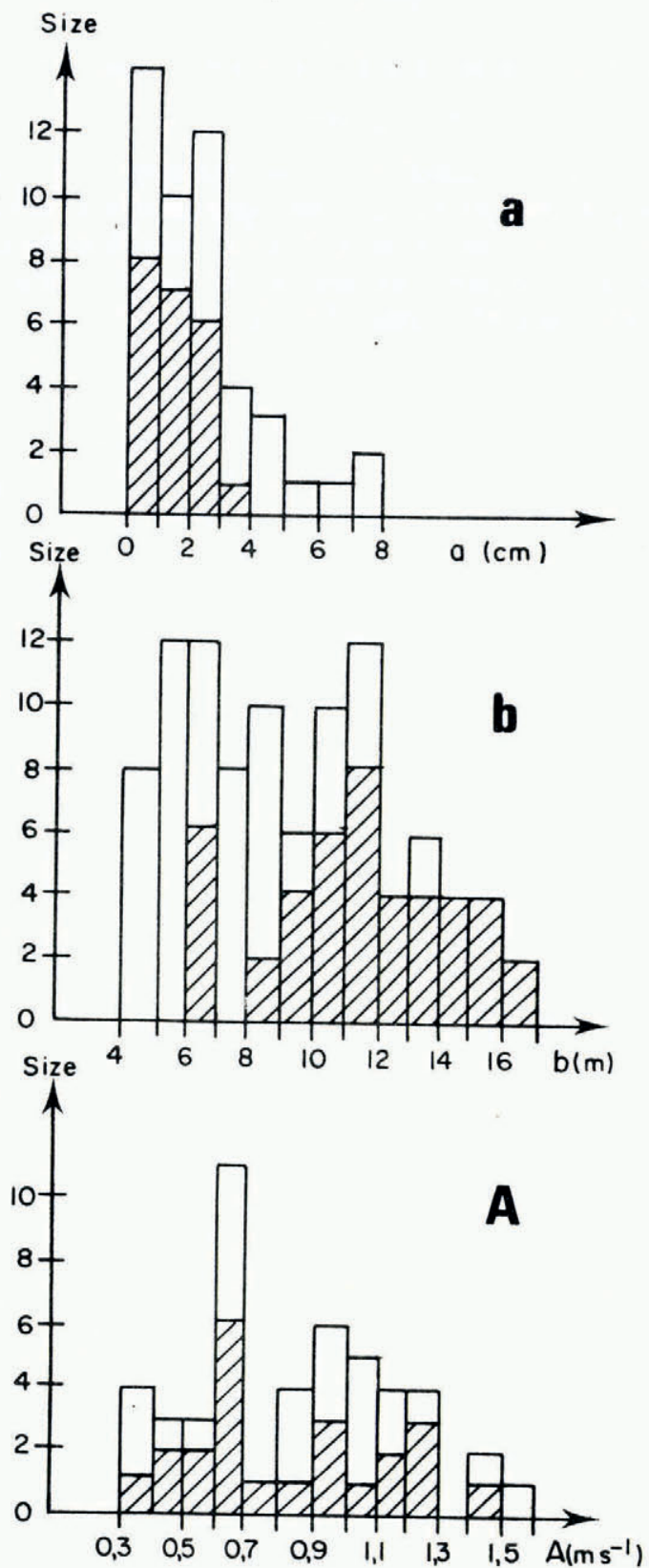

Fig. 4. Histograms of $a, b$ and $A$ distributions. Shaded zones characterize the "nocturnal" period and the white zone the "diurnal" period. 


$$
\operatorname{erf}(y)=\frac{2}{\sqrt{ } \pi} \int_{0}^{y} \exp \left(-x^{2}\right) \mathrm{d} x .
$$

We have attempted to fit the experimental profiles by the equation:

$$
\theta_{z}=T_{0} \operatorname{erf}(z / c) \text {. }
$$

Temperature $T_{0}$ and $c$ are calculated from the measured points at $1 \mathrm{~m}$ and $9 \mathrm{~m}$. The fit is bad; for each of the profiles the temperature gradients are too strong between $0.5 \mathrm{~m}$ and $2 \mathrm{~m}$ (Fig. 5). This divergence seems to stem from the fact that Equation (7) characterizes a forced flow above a plane surface, while we were in the presence of a flow driven by density gradient above an inclined surface of average slope $7^{\circ}$.

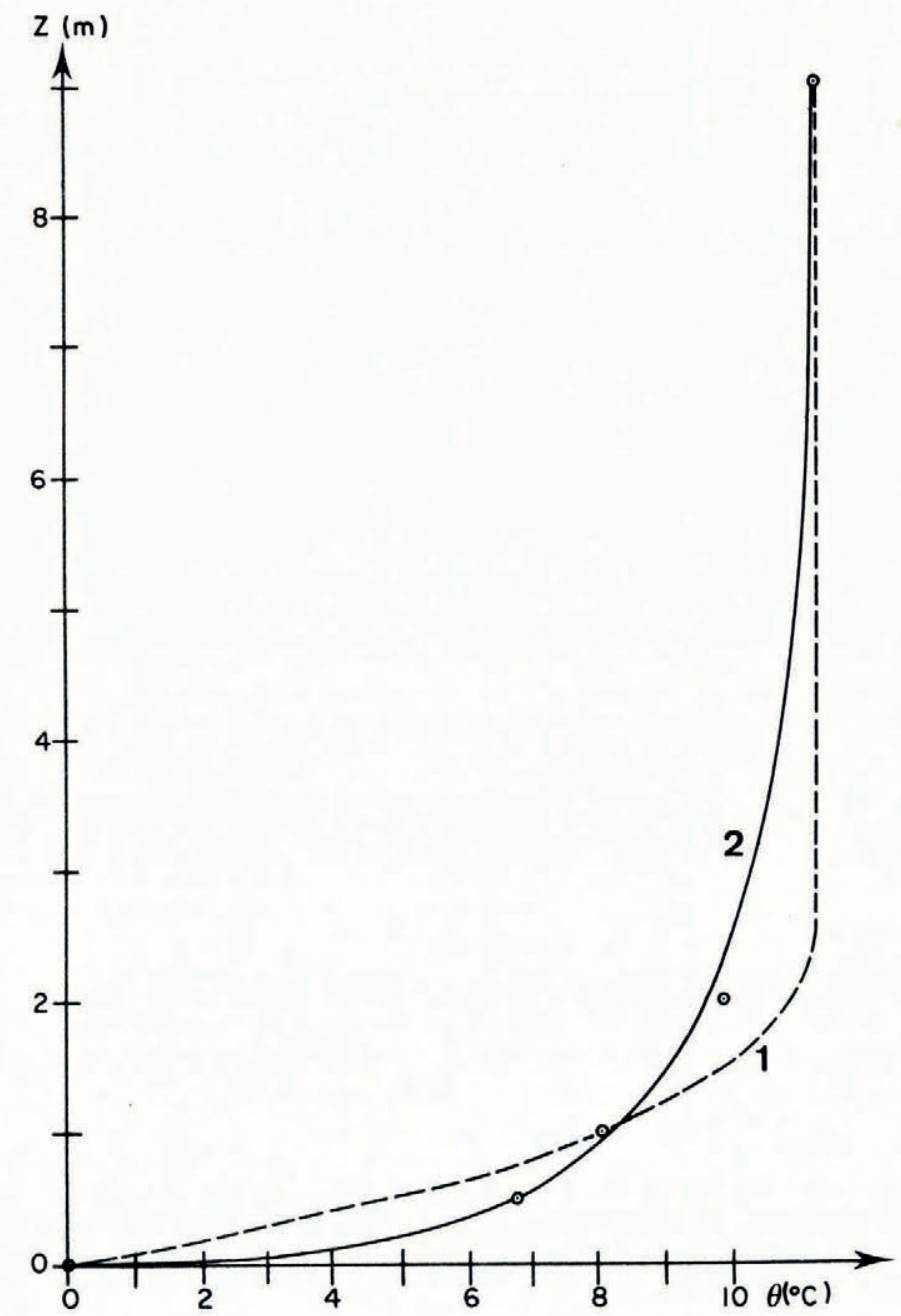

Fig. 5. Fitting of a mean temperature profile (07.00 to $17.00 \mathrm{~h} 20$ September 1970) by two equations:

(I) $\theta_{z}=I I .38 \mathrm{erf}(z / I .3 I)$;

(2) $\theta_{z}=2.49 \ln (z / 0.034) \exp (-z / 44 . I)$. 
In order to fit the experimental profiles we chose an empirical law similar to that for velocities:

$$
\theta_{2}=A^{\prime} \ln \left(z / a^{\prime}\right) \exp \left(-z / b^{\prime}\right)+\theta_{0} .
$$

The four parameters $A^{\prime}, b^{\prime}, a^{\prime}$ and $\theta_{0}$ require four measuring points in order to be calculated, which prevents us from evaluating the quality of the fit. We will therefore limit ourselves to profiles for which the glacier surface is at $0^{\circ} \mathrm{C}$ ("diurnal" period) then $\theta_{0}=0$. Figure 5 shows the average values of "diurnal" temperatures ( $08.00 \mathrm{~h}$ to $17.00 \mathrm{~h}$ on 20 September 1970) fitted by Equations (7) and (8).

3.2.3. Inversion of temperature gradients. In the hours after sunrise and while the weather is clear, two things contribute to a strong reheating of the air layer nearest to the glacier:

-at sunrise, the temperature $\theta_{0}$ of the surface, up until now negative because of the radiation of the ice, goes back to $o^{\circ} \mathrm{C}$. At equal ambient temperatures, there is therefore a reheating of the first decimetres of air and modification of the temperature profiles.

-with the beginning of melting the glacier surface constitutes a source of water vapour and it is thought that the absorbtion of the infrared leads to a selective reheating of the wettest, that is the lowest layers. A maximum appears in the temperature profiles and the sensible heat fluxes on the two sides of this maximum are of opposite sign (Fig. 6).

In the Nevacerrada pass in the Sierra Guadarrama northwest of Madrid, while studying the heat balance above the snow, La Casinière (1974) encountered this same inversion of sensible heat flux.

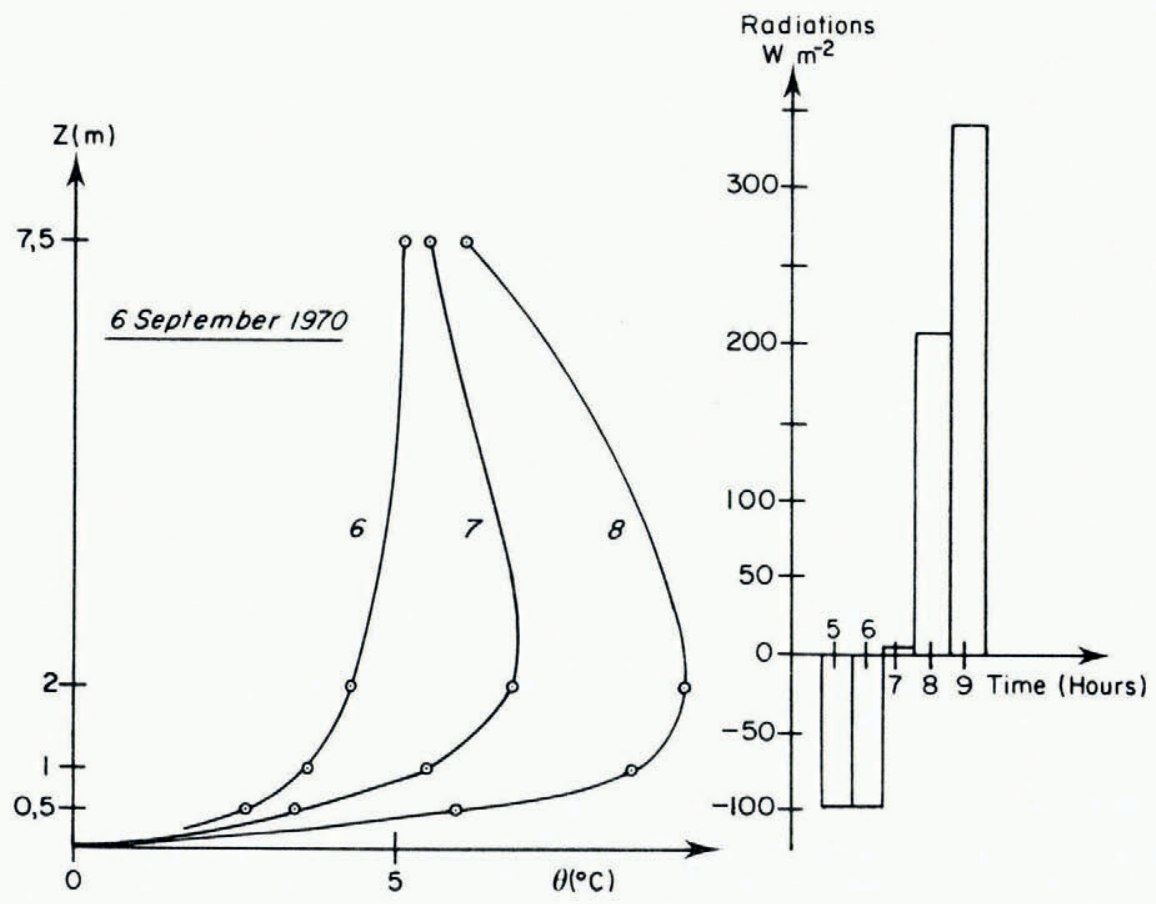

Fig. 6. Left: Heating of the lowest layer of air at sunrise. Right: Corresponding variations of radiation. 
3.2.4. Correlations between wind-speed and temperature gradient. The glacier wind results from a flow by density difference; it is normal to find a relation between the temperature gradients and the wind velocity that results from it.

In Figure $7 \mathrm{~A}$, we have used simultaneously the time evolution of the temperature gradient $\left(\theta_{9.5}-\theta_{0.5}\right)$ and the wind velocity at $0.5 \mathrm{~m}\left(u_{0.5}\right) .72$ pairs of values shown in Figure $7 \mathrm{~B}$, give the linear correlation:

$$
u_{0.5}=0.367 \mathrm{~m} \mathrm{~s}^{-1} \operatorname{deg}^{-1}\left(\theta_{9.5}-\theta_{0.5}\right)+0.617 \mathrm{~m} \mathrm{~s}^{-1} \text {. }
$$

The correlation coefficient of 0.637 is very significant at the o.or level.
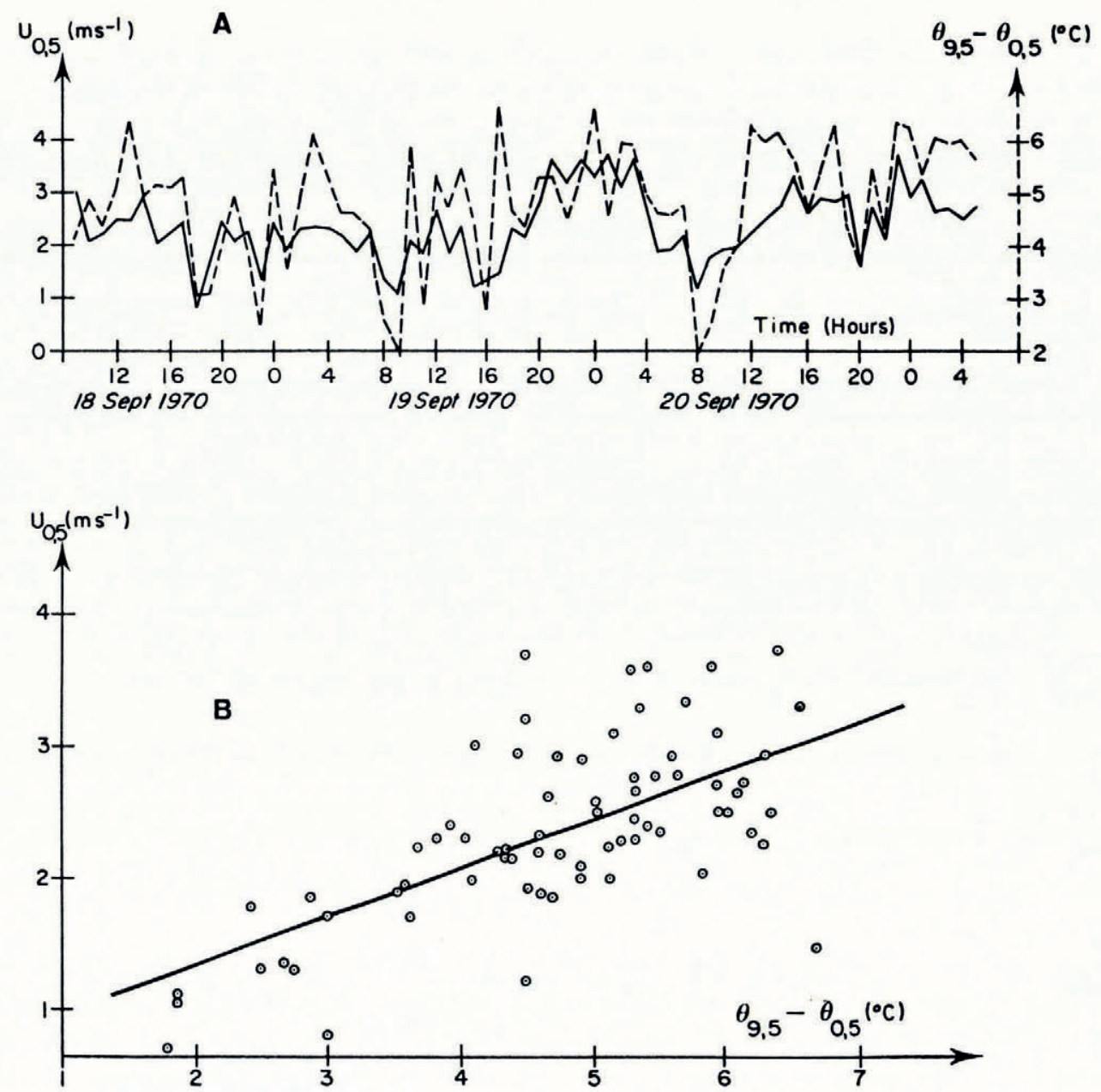

Fig. 7. A:Variation with time of wind velocity at $0.5 \mathrm{~m}$ and gradient of temperature between $9.5 \mathrm{~m}$ and $0.5 \mathrm{~m}$. B: Correlation between wind-speed $\left(v_{0.5}\right)$ and temperature gradient $\left(\theta_{0.5}-\theta_{0.5}\right)$.

\subsection{Regime changes}

In an hour's time, a "classical" regime with logarithmic wind-speed profiles can change suddenly into a glacier-wind regime. At equal ambient temperatures, we therefore observe a cooling of the first two metres. This cooling exceeded $2^{\circ} \mathrm{C}$ at $0.5 \mathrm{~m}$ as shown in Figure 8 . 

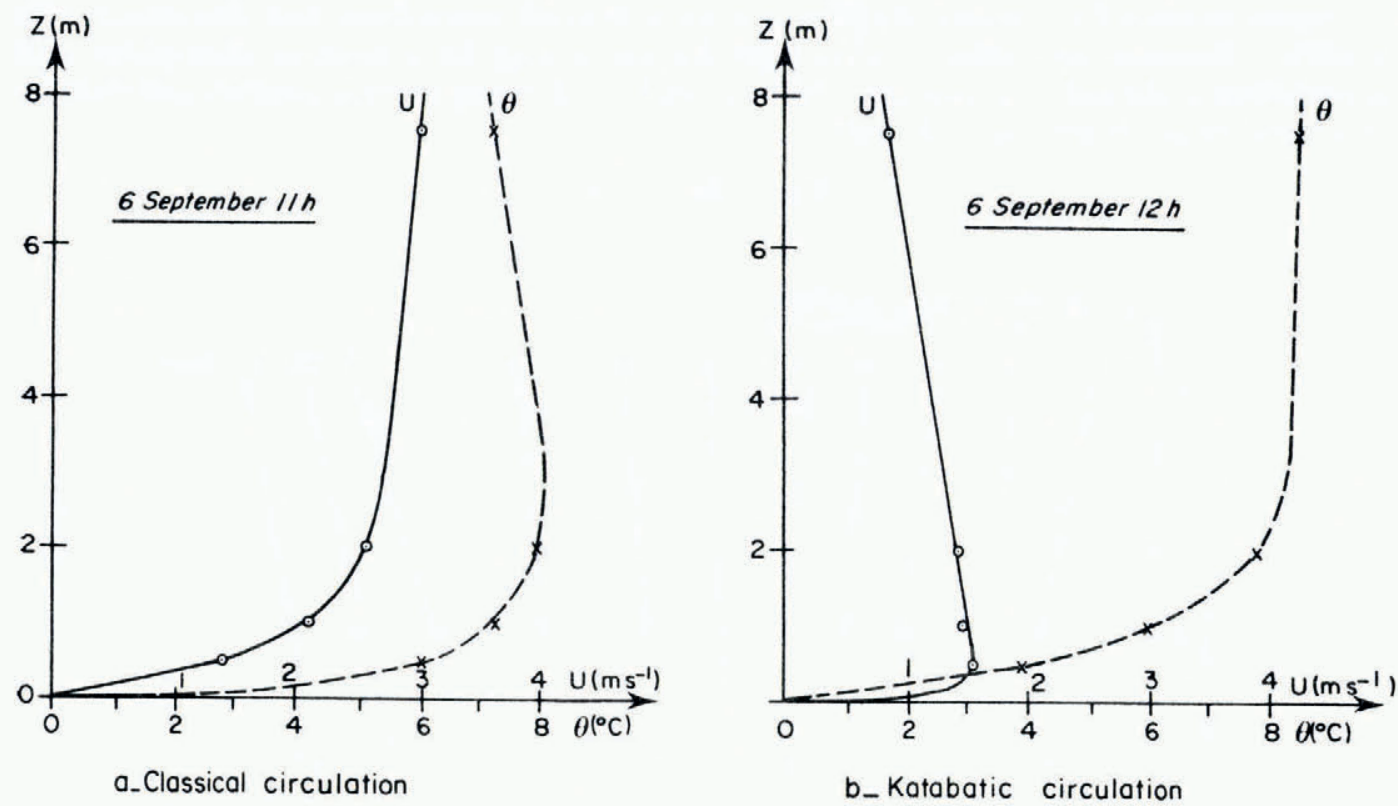

Fig. 8. Regime change over the glacier.

Transition periods can equally be observed during which the geostrophic wind is not strong enough to disperse completely the glacier wind. The curves in Figure $9 \mathrm{~A}$ characterize the passage of a katabatic regime to a strong southerly wind. In Figure $9 \mathrm{~B}$, we have plotted the coefficients $a$ and $b$ calculated using Equation (6). At $19.00 \mathrm{~h}$ the coefficient $b$ becomes very large $(b>100 \mathrm{~m})$; for the layer that interested us, the profiles can therefore be considered logarithmic. The mixing of air layers increases with this southerly wind (Fig. 9C).

\section{The balances}

\section{I. Calculation of average fluxes of sensible heat and water vapour}

Prandtl's theory on turbulent transfers leads to the following relations. For transfer of momentum:

$$
\tau=\rho K_{\mathrm{M}} \frac{\mathrm{d} u}{\mathrm{~d} z}
$$

where $\tau$ is the shear stress, and $K_{\mathbf{M}}$ the turbulent exchange coefficient of momentum.

For heat transfer:

$$
Q=-K_{\mathrm{H}} C_{p} \rho \frac{\mathrm{d} \theta}{\mathrm{d} z}
$$

where $\theta$ is the temperature, $C_{p}$ the specific heat capacity, and $K_{\mathrm{H}}$ the turbulent exchange coefficient of heat.

For water-vapour transfer:

$$
E=-\kappa_{\mathrm{E}} \frac{\mathrm{d} m}{\mathrm{~d} z}
$$

where $m$ is the mass of water vapour, and $K_{\mathrm{E}}$ the turbulent exchange coefficient of water vapour. 
Many workers have shown $\kappa_{\mathrm{H}} / K_{\mathrm{M}}=\mathrm{I}$ for a neutral atmosphere and decreasing with stability. Businger and others (I97I) give $\kappa_{\mathbf{H}} / K_{\mathbf{M}}=\mathrm{I} .35$ for a neutral atmosphere and diminishing as the stability increases. With conditions of strong enough stability that characterize our measures we assumed that:

$$
\kappa_{\mathbf{M}}=\kappa_{\mathbf{H}}=\kappa_{\mathbf{E}}
$$
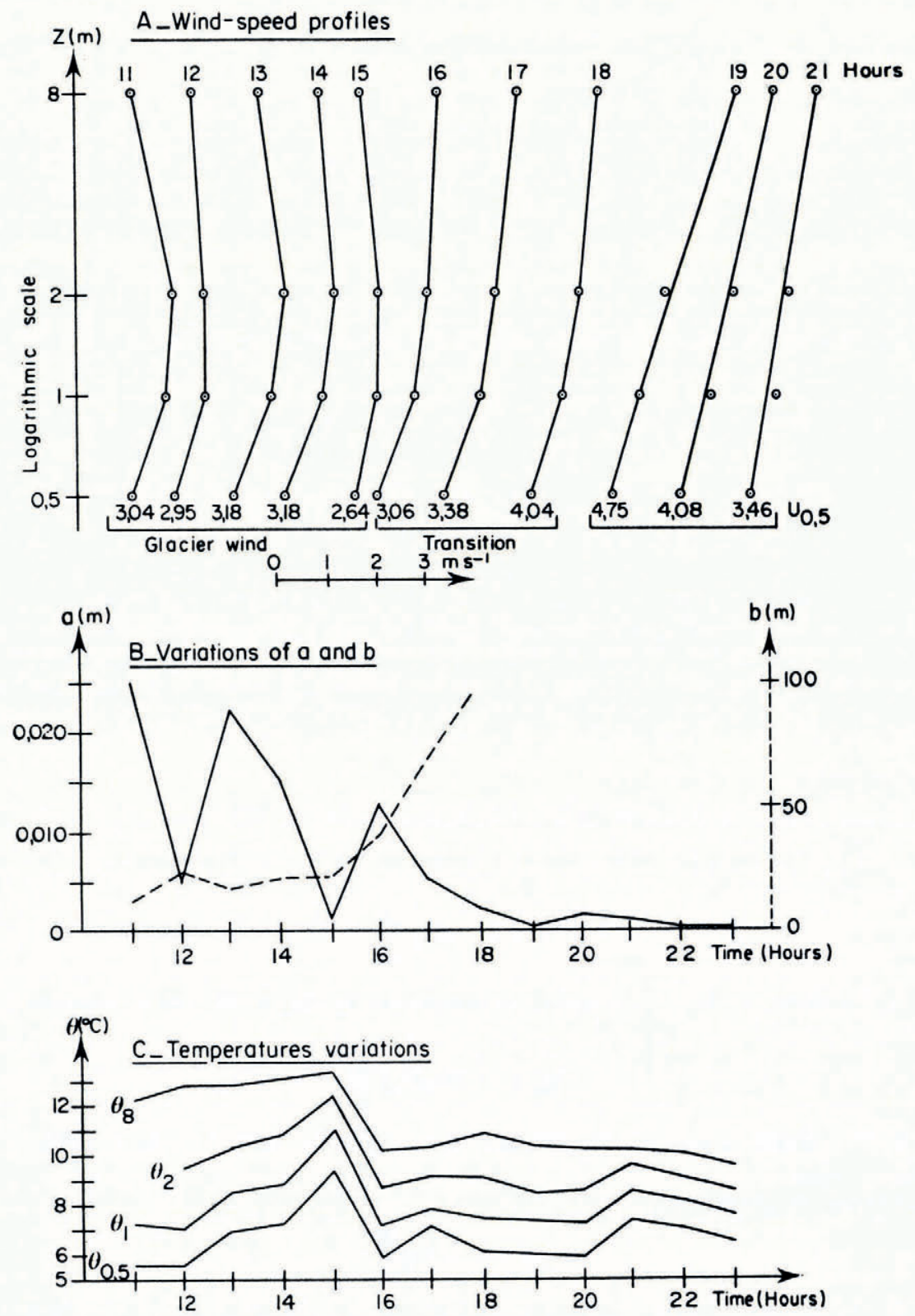

Fig. 9. 7 September 1970. Transition between a glacier wind and a geostrophic wind blowing from south. 
We calculated hourly average fluxes of sensible and latent heat for a period extending from 30 August to 15 September 1969 . For them, we considered the wind-speed profiles to be logarithmic and we computed $K_{\mathrm{M}}, Q$ and $E$, at $0.72 \mathrm{~m}$ if the glacier wind blows, that is below the maximum of the velocities, and at $1.08 \mathrm{~m}$ in all other cases.

$\kappa_{\mathbf{M}}$ is defined according to the Equation (II) and

$$
\tau=\rho u_{*}^{2}, \quad K_{\mathrm{M}}=u_{*} k z \text {. }
$$

$Q$ is simply calculated from the gradients of temperature (Equation (12)) and $L_{\mathrm{S}} E$ by Equation (13) using the conversion:

$$
\frac{\mathrm{d} m}{\mathrm{~d} z}=0.622 \frac{\rho}{p} \frac{\mathrm{d} f}{\mathrm{~d} z} .
$$

\subsection{Analysis of the energy balance}

For two days when the average fluxes exchanged between the ice and the atmosphere were particularly important ( 1 I and 12 September I969), a histogram of their variations has been made (Fig. 10). On this figure, the flow of the Rieu Blanc is also plotted. The delay

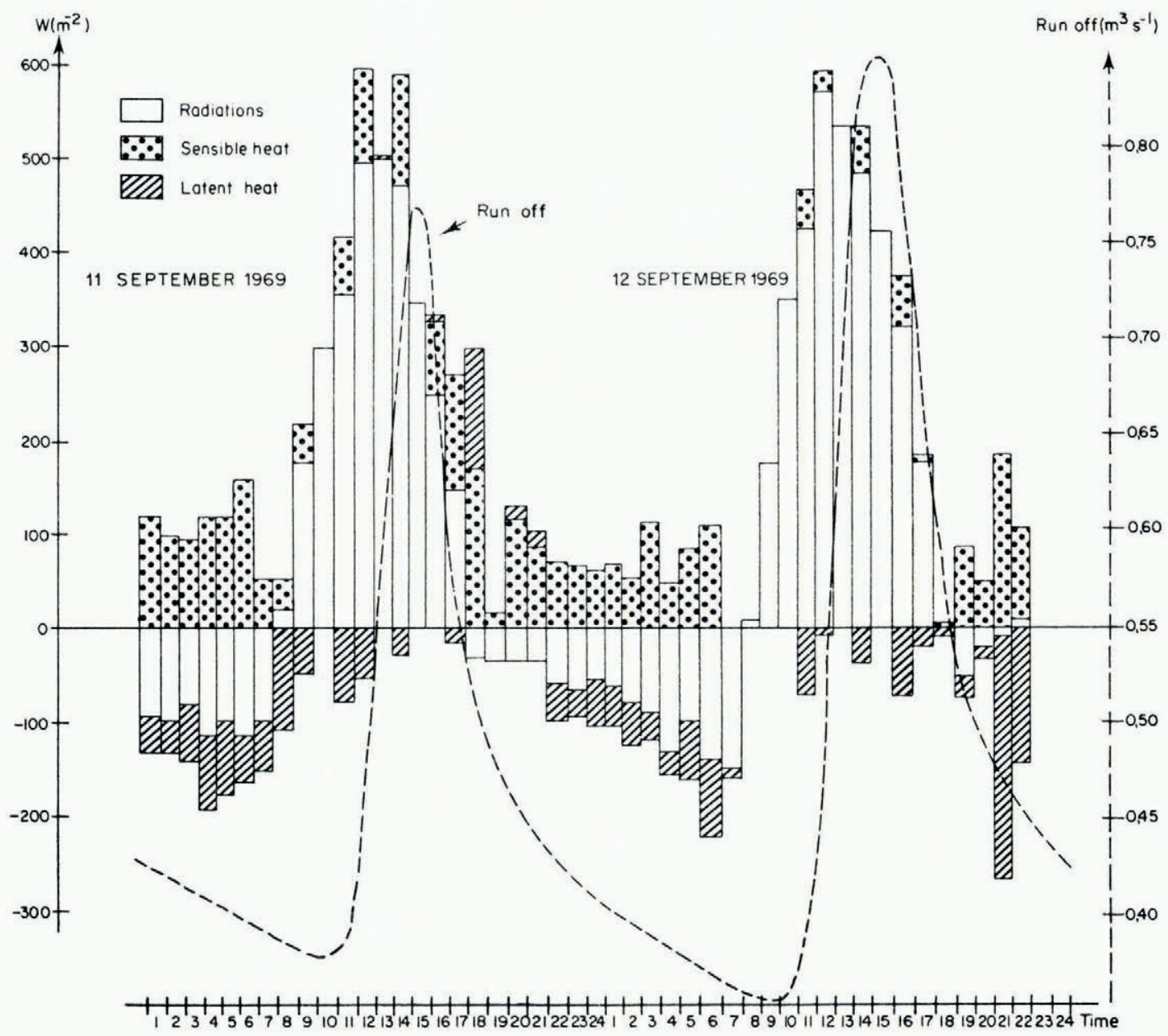

Fig. 1o. Hourly heat fluxes and Rieu-Blanc run-off. 
that appears between the variations in flow and those of the total flux received by the glacier correspond to the flow time of the melt water down to the measuring point located at $2000 \mathrm{~m}$ from the meteorological station.

From 30 August to ${ }_{15}$ September 1969 , we plot on Figure 1 i the daily balances and the mean melting measured at the four stakes (with ice density of $0.9 \mathrm{Mg} \mathrm{m}^{-3}$ ). In cutting off the quantity of heat necessary for the ice ablation, the end result must be zero. In fact, this is not always realized, because beside measurement errors and approximations, it is necessary to take into consideration that flux exchanged between the atmosphere and the glacier was neglected when the wind velocity fell below $1 \mathrm{~m} \mathrm{~s}^{-1}$. Precipitation also upset the measurement of net radiation when it was deposited on the thermopile. This is particularly evident during the rainy episodes indicated in Figure $\mathbf{I}$ I.

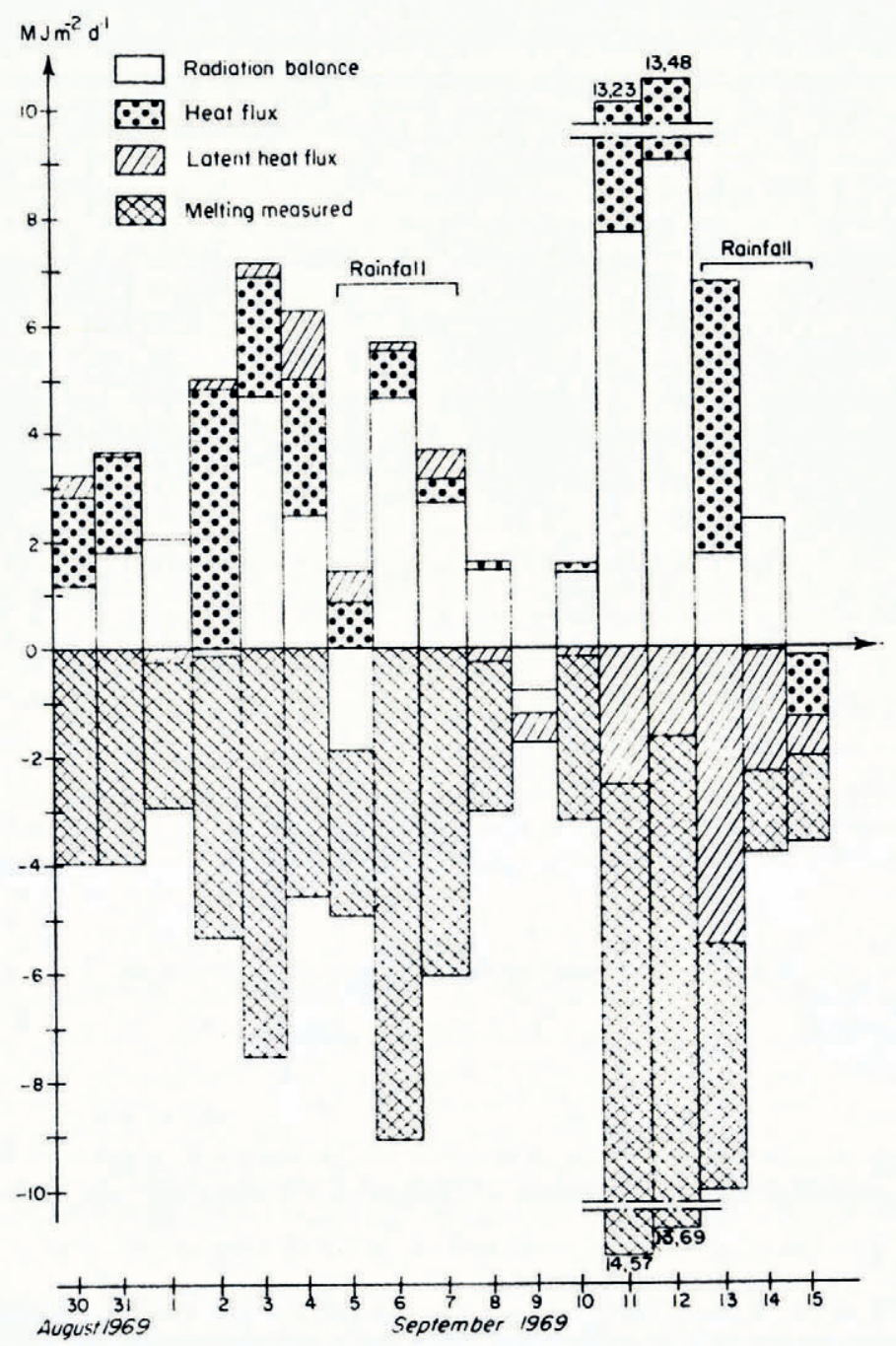

Fig. II. Daily heat fluxes compared with daily measured melting. 
The daily average fluxes calculated on eleven days not disturbed by precipitation were: radiation: $2.76 \mathrm{MJ} \mathrm{m}^{-2} \mathrm{~d}^{-1}$, sensible heat: $2.09 \mathrm{MJ} \mathrm{m}^{-2} \mathrm{~d}^{-1}$, latent heat: $-0.30 \mathrm{MJ} \mathrm{m}^{-2} \mathrm{~d}^{-1}$.

The sum of the eleven daily fluxes leads to the comparison: ablation from heat-balance measurement: $168 \mathrm{~mm}$ of ice, ablation from direct measurement (stakes): $190 \mathrm{~mm}$ of ice.

\section{Conclusion}

This study shows the diversity of the regimes that can be established on the surface of a glacier under the influence of glacier wind, local winds, and regional fluxes. This diversity involves notable difficulties when we want to calculate the heat flux; the transfers in the presence of strong stratification being poorly known.

In the Vallée Blanche (Massif du Mont Blanc, France) at $3500 \mathrm{~m}$ in altitude, La Casinière (1974) found that sensible heat balance represented only $5 \%$ of the total balance. There is, therefore, a rapid decrease of the sensible heat flux with the altitude.

\section{Acknowledgements}

I would like to thank Professor Lliboutry, Director of the Laboratoire de Glaciologie of C.N.R.S. who entrusted to me the realization of this work and M. Poggi whose experience and advice were precious to me.

MS. received 2 January 1974 and in revised form 13 March 1974

\section{REFERENCES}

André, H. 1964. Hydrométrie pratique des cours d'eau. [Jaugeages par la méthode de dilution.] [Grenoble], E.N.S.E.H.R.M.A. Section Hydraulique. Faculté des Sciences, Certificat de Potamologie.

Arya, S. P. S. 1972. The critical condition for the maintenance of turbulence in stratified flows. Quarterly Journal of the Royal Meteorological Society, Vol. 98, No. 416, p. 264-73.

Businger, W., and others. 197I. Flux-profile relationships in the atmospheric surface layer, [by] J. A. Businger, J. C. Wyngaard, Y. Izumi and E. F. Bradley. Journal of the Atmospheric Sciences, Vol. 28, No. 2, p. 181-89.

Ellison, T. H., and Turner, J. S. 1959. Turbulent entrainment in stratified flows. Fournal of Fluid Mechanics, Vol. 6, Pt. 3, p. 423-48.

Ellison, T. H., and Turner, J. S. 1960. Mixing of dense fluid in a turbulent pipe flow. Journal of Fluid Mechanics, Vol. 8, Pt. 4, p. 514-28.

Grainger, M. E., and Lister, H. 1966. Wind speed, stability and eddy viscosity over melting ice surfaces. Journal of Glaciology, Vol. 6, No. 43, p. 101-27.

Hoinkes, H. C. 1954. Der Einfluss des Gletscherwindes auf die: Ablation. Zeitschrift für Gletscherkunde und Glazialgeologie, Bd. 3 , Ht. 1, p. 18-23.

La Casinière, A. C. de. 1974. Heat exchange over a melting snow surface. Journal of Glaciology, Vol. 12, No. 67, p. 55-72.

Lliboutry, L. A. 1974. Multivariate statistical analysis of glacier annual balances. Journal of Glaciology, Vol. 13, No. 69 , p. $371-92$.

Poggi, A., and others. 1967. Anémographe à téléindication digitale, [par] A. Poggi, A. Chaillou, L. Philippe. (In Schram, K., and Thams, J. C., ed. 9. Internationale Tagung für Alpine Meteorologie. In Brig und Zermatt, 14.-17. Sept. 1966. Veröffentlichungen der Schweizerischen Meteorologischen Zentralanstalt, Nr. 4, p. 266-71.)

Prandtl, L. 1952. Guide à travers la mécanique des fluides. Paris, Dunod.

Priestley, C. H. B. 1959. Turbulent transfer in the lower atmosphere. Chicago, University of Chicago Press.

Sutton, O. G. 1953. Micrometeorology. New York, McGraw-Hill Book Co., Inc.

Webb, E. K. 1970. Profile relationships: the log-linear range, and extension to strong stability. Quarterly Journal of the Royal Meteorological Society, Vol. 96, No. 408, p. 67-9o. 